\title{
IVORY GLACIER, NEW ZEALAND, AN I.H.D. REPRESENTATIVE BASIN STUDY
}

\author{
By P. W. Anderton* and T. J. Cihinn \\ (Water and Soil Division, Ministry of Works and Development, P.O. Box I479, Christchurch, \\ New Zealand)
}

\begin{abstract}
Anstracr. Mass, water, and energy balances were measured at the Ivory Glacier, South Island, New Zealand from 1969 to 1975 as part of an 1. H.1). programme of representative basin studies. Ivory Glacier is a small cirque glacier within the high-precipitation maritime environment of Westland and was chosen initially for convenience of study rather than representativeness. Mass-balance investigations included a detailed study of the sampling efficiency of a pole network. Annual mass balance was consistently negative during the study period. The run-off pattern was dominated by rain. The estimated annual mean precipitation is $9630 \mathrm{~mm}$ for $197 \mathrm{1}-75$. Snow represents about $25 \%$ of annual precipitation. Melt contributed $21 \%$ of run-off including $9^{\circ}$ contributed by melt of perennial snow and ice. The relative contributions of different fuxes to the encrgy balance during summer are: net radiation $52 \%$, sensible heat $29 \%$, and latent heat $17 \%$. Heat content of precipitation contributes significantly to the energy balance during individual rain-storms and is probably significant during periods of high precipitation in spring and autumn. Climatic characteristics and behaviour of Ivory Glacier appear to follow regional trends in the Southern Alps and the glacier is considered to be reasonably representative.
\end{abstract}

Résumé, Ivory Glacier, Nonvelle-Zélande, étude d'un bassin representatif de la D.H.I. On a entrepris des études de bilan de masse, de bilan hydrologique et énergétique sur le Ivory Glacier, South Island, Nouvelle-Zélande, de 1969 a 1975 dans le cadre d'un programme de la D.H.I. d'études de bassins représentatífs. Ivory Glacier est un petit glacier de cirque dans l'environnement maritime très pluvieux du Westland et a été choisi au début plus pour la commodité des études que pour sa représentativité. Les études de bilan comprenaient une étude détaillée de l'efficacité de la distribution d'un réseau de balises, Le bilan annuel fut régulièrement négatif pendant la période d'étude. L'allure des écoulements hydrologiques saisonniers fut dominée par la pluie. La précipitation moyenne annuelle estimée est de $9630 \mathrm{~mm}$ pour 1971-75. L'accumulation de neige représente environ $25 \%$ de la précipitation annuelle. La fusion contribue pour $21 \%$ aux écoulements dont 9\% fourni par la fusion de la glace ou de neige permanente, Les contributions relatives des différentes sources au bilan énergétique pendant l'été sont: la radiation nette $5,2 \%$, la chaleur sensible $29 \%$ et la chaleur latente $17 \%$. Le contenu calorifique des précipitations apporte une contribution significative au bilan énergétique pendant les épisodes pluvieux individuels et est probablement également significatif pendant les périodes de pluies abondantes du printemps et de l'automne. Les caractérístíques climatiques et le comportement du Ivory Glacier apparait en bon accord avec les tendances régionales dans les Southern Alps et l'on peut maintenant consjérer le glacier comme raisonnablement représentatif.

Zusammenfassung, Jiory Glacier, Neuseeland, eine Untersuchung eines I.H.D. repräsentativen Glelscherbeckens, Am I vory Glacier auf der Südinsel von Neusecland wurden von 1969 bis 1975 Massen-, Wasser- und Energiebilanz als Teil eines I.H.D. Programmes von Studien an reprasentativen Gletscherbecken gemessen. Ivory Glacier ist ein kleiner Kargletscher in der niederschlagsreichen, maritimen Region von Westland; die Wahl fiel auf ihn anfänglich eher aus Gründen der Bequemlichkeit als aus solchen der Repräsentanz. Die Untersuchungen zur Massenbilanz schlossen eine genaue Studie über die Beobachtungszuverlässigkeit in einem Stangennetz cin. Die Jahresmassenbilanz war während der Untersuchungsperiode ständig negativ. Der Abfluss hing vor allem vom Regen ab. Der Niederschlag betrug im Jahresmittel von $197 \mathrm{t}-75$ schätzungsweise $9630 \mathrm{~mm}$. Hiervon entfielen etwa $25 \%$ auf Schnee. $21 \%$ des Abflusses cntstammten der Schmelze, worin $9 \%$ aus dem Abschmelzen von Altschnee und Eis enthalten sind. Die relativen Beiträge der verschiedenen Quellen zur Energiebilanz, während des Sommers sind: Netto-Strahlung $52 \%$, fühlbare Wärme $29 \%$, latente Wärme $17^{\prime \prime} \%$. Der Wärmegehalt des Niederschlages trägt wesentlich zur Energiebilanz während einzelner Unwetter bei und spielt vermutlich während der niederschlagsreichen Perioden im Frühling und Herbst eine entscheidende Rolle. Die klimaabhängigen Eigenschaften und das Verhalten des Ivory Glacier scheint dem regionalen Trend in den Südlichen Alpen zu folgen; der Gletscher ist daher derzeit als ausreichend repräsentativ.

\section{INTRODUCTION}

The purpose of this paper is to summarize the results of studies of Ivory Glacier, South Island, New Zealand during the period $1969-75$. These studies are part of the New Zealand contribution to the International Hydrological Decade.

\footnotetext{
* Present address: N.Z. Gcological Survey, Lower Hutt, New Zealand.
} 
Choice of a Representative Basin

A programme establishing representative basins for the hydrological regions in New Zealand was adopted in 1965 by the Ministry of Works (New Zealand. National Water and Soil Conservation Organisation, 1970). The main criterion used for selection of a basin was the representativeness of the basin's hydrological characteristics of those of its region.

Three principal research objectives were defined as:

(I) Prediction of low and mean flows within each region.

(2) Study of hydrological processes.

(3) Development of mathematical and/or physical prediction models.

The glacial hydrological region (Toebes and Palmer, 1969) comprises those parts of the Southern Alps where perennial snow and ice are of major hydrological significance. The greater part of this region is centred on the Mt Cook and Westland National Parks and

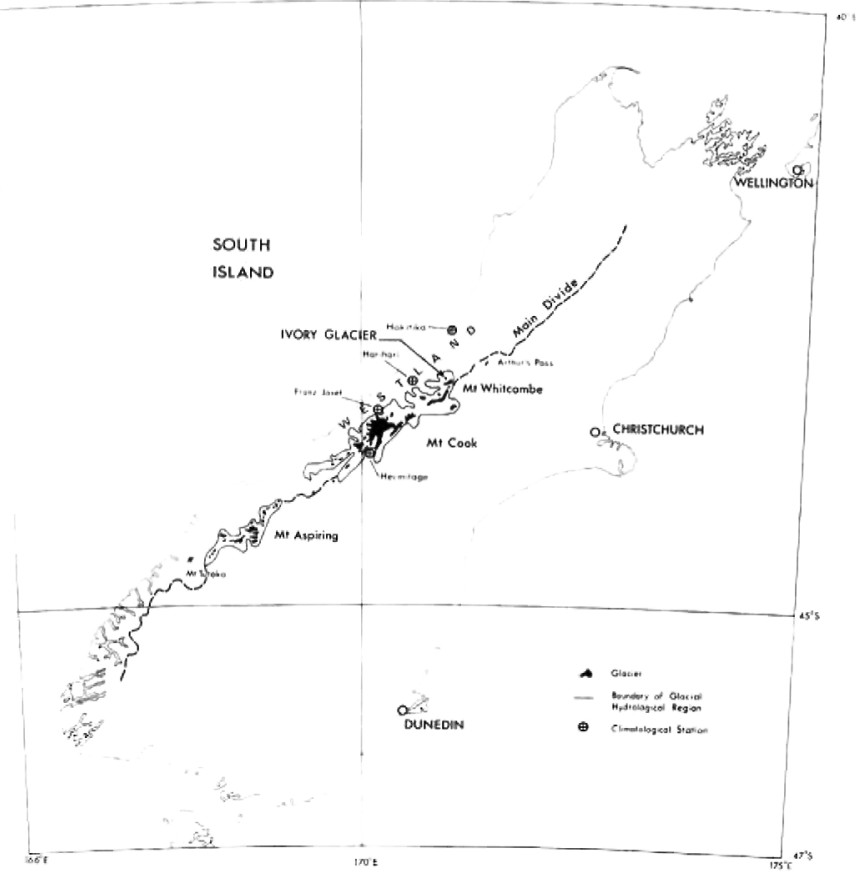

Fig. I. Map of South Island, New Zealand, showing glacier regions and location of Ivory Glacier and principal alpine slimatoLogical stations. 
extends north to Mt Whitcombe (Fig. I). A smaller area to the south is centred on the Mt Aspiring National Park.

The selection of a representative basin for the glacial region was initially based on criteria used to establish other representative basins in the little-studied hydrological regions along the chain of the Southern Alps. Where possible, basins were selected which drain the full altitudinal range of the region and which have river gauging sites where bed losses are minimized. In selecting a glacial basin, it was not considered whether fluctuations of the glacier itself were representative of glacier fluctuations in the region. This would have been impossible to assess because of the lack of any systematic records of glacier fluctuations in the Southern Alps except for observations of the termini of Franz Josef and Fox Glaciers (Sara, 1968, 1970).

The Hooker Glacier basin was initially chosen to represent the region. This basin is $22 \mathrm{~km}^{2}$ in area, lies immediately to the west of Mt Cook, and ranges in altitude from 730 to $3765 \mathrm{~m}$. Initial investigations showed that the size and complexity of the basin precluded satisfactory assessment of mass balance and components of the water balance, and the proposed study was abandoned.

Between I966 and 1968 many more glacier basins were investigated (Chinn and Bellamy, I970). Available maps and photographs were examined and the more promising glaciers were observed on reconnaissance flights. The most promising glaciers were visited. Very few glaciers were found suitable for detailed hydrological studies and these few glaciers were probably unrepresentative of the region. Most glacier basins in the Southern Alps are unsuitable because of inaccessibility, danger from avalanches, steep glacier slopes with ice falls, or braided stream channels with no satisfactory gauging sites.

The criterion of representativeness had to be ignored and the selection of a glacier basin eventually was based on criteria related to the suitability of the basin for repeated, detailed surveys. Five glaciers were selected for final consideration. Four of these werc climinated after inspection revealed danger from avalanches or lack of a suitable stream-gauging sitc. The presence of an excellent gauging site was the most important factor influencing the decision to study Ivory Glacier, which was virtually unknown and un-named at the time, and lies near the northern limits of glacier occurrence in the Southern Alps.

\section{IVORY GLACIER}

Ivory Glacier is located at lat. $43^{\circ} 08^{\prime} \mathrm{S}$., long. $170^{\circ} 55^{\prime} \mathbf{E}$. in the headwaters of Waitaha River within the high-precipitation, maritime environment of Westland (Fig. I). It is a small cirque glacier, $0.8 \mathrm{~km}^{2}$ in area and extending from 1400 to $1700 \mathrm{~m}$ in altitude (Fig. 2), It owes its continued existence largely to the south-facing aspect of the cirque. The glacier calves into a small proglacial lake which is about $40 \mathrm{~m}$ deep adjacent to the terminus.

The cirque basin, cut in biotite schist, has an area of $2.2 \mathrm{~km}^{2}$ and ranges in altitude from I 400 to $2080 \mathrm{~m}$. A single run-off channel, cut through massive unweathered schist, runs for about $100 \mathrm{~m}$ from the lake outlet before descending a series of waterfalls. No significant loss of water by sub-surface flow was found, except for a small perennial spring at the foot of the first waterfall.

Access to the glacier for surveys is only practicable by helicopter.

\section{RESEARGH PROGRAMME}

Within the framework of the representative-basin programme, the research carried out in the Ivory basin can be classified as a study of hydrological processes. The basin is too small to provide information directly useful for predicting stream flow within the glacial region.

The aims of the project were:

(I) To provide long-term hydrological records. 


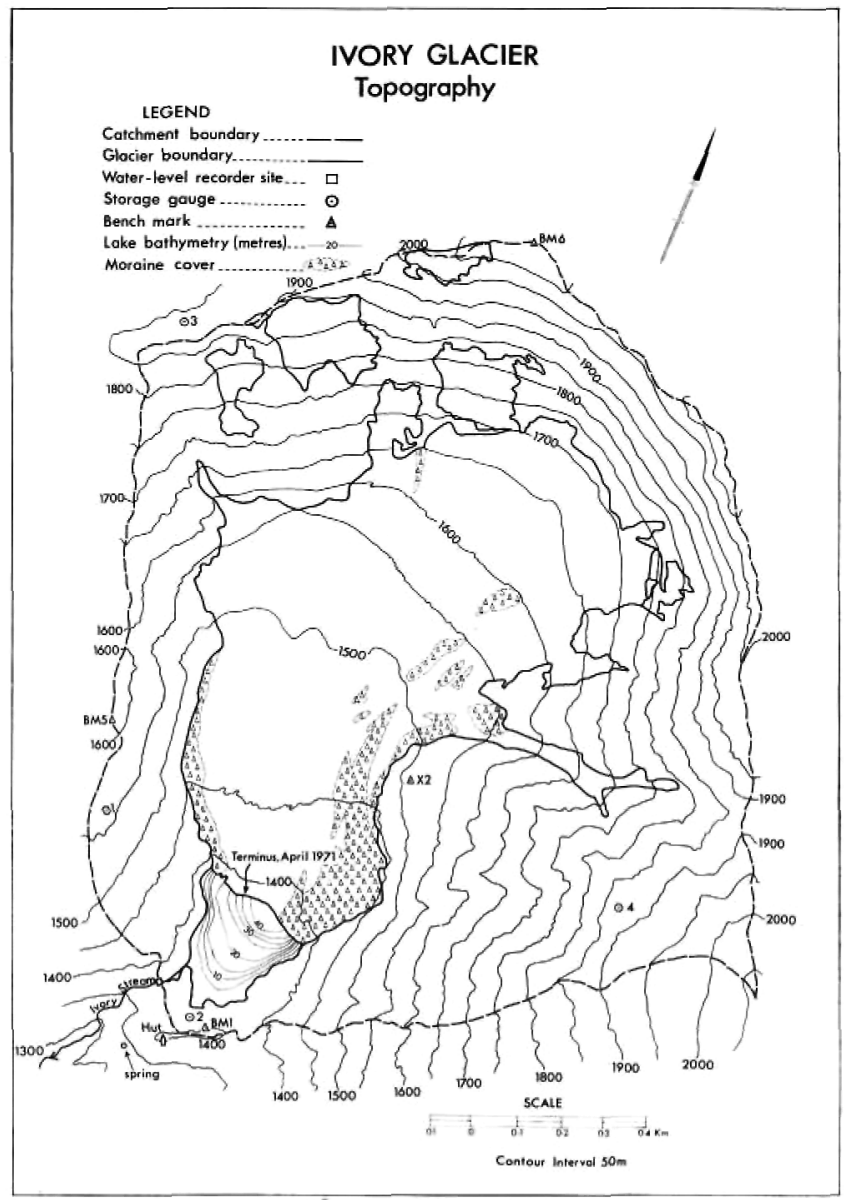

Fig. 2. Map of Itory Glacier basin. 
(2) To investigate relationships between water balance, mass balance, energy balance, and climatic characteristics of the basin, as proposed for the Combined glacier balances programme of the International Hydrological Decade (I.H.D.).

(3) To improve observational and analytical techniques in snow and ice hydrology in New Zealand. Previous studies of mass balance in New Zealand were confined to the Tasman Glacier (Goldthwait and McKellar, I962; Chinn, I969) and the small Whakapapanui Glacier on Mt Ruapehu in North Island (Thompson and Kells, 1973).

The research programme that was undertaken largely fulfilled these objectives and included the following studies:

(1) Mass balance.

(2) Water balance.

(3) Energy balance, based on short-term micro-climatological measurements.

(4) Collection of long-term climatological records and development or testing of automatic recording instruments.

Some results of these studies have been presented in a serics of reports by the New Zealand Ministry of Works and Development (Chinn and Bellamy, 1970; Anderton and Chinn, 1973; Anderton, $1976[\mathrm{a}]$, [b]).

\section{Mass balance}

\section{Measurement}

A photogrammetric map of the basin at a scale of 1 : 2500 was prepared from aerial photographs taken in April 1971. Thirty sampling sites were marked for measurements of accumulation and ablation at the glacier surface (Fig. 3). This network was measured at intervals of approximately 3 months.

At the peak of the accumulation season thickness of the snow-pack on the glacier varied from $\mathrm{I}-2 \mathrm{~m}$ on the lower tongue to about $6 \mathrm{~m}$ at the head of the glacier. Small avalanches are common, and parts of the network were buried each winter. Twice during the study large avalanches travelled half the length of the glacier, and during the winter of 1976 , after the end of the project, an exceptionally large avalanche traversed the entire length of the glacier.

Water equivalent of the snow-pack was determined from snow pits and snow sampler measurements. New-snow density generally ranged from 0.15 to $0.20 \mathrm{Mg} / \mathrm{m}^{3}$. The mean snow-pack density usually reached $0.5 \mathrm{Mg} / \mathrm{m}^{3}$ by mid-winter, $0.6 \mathrm{Mg} / \mathrm{m}^{3}$ by the start of the ablation season and $0.65-0.70 \mathrm{Mg} / \mathrm{m}^{3}$ by the end of the summer. Ice ablation was recorded by polyvinylchloride poles installed by hot-point drill or a SIPRE ice drill. Annual ablation close to the terminus ranged from 6 to $9 \mathrm{~m}$ of ice.

A study of the sampling efficiency of the pole network was carried out over a $29 \mathrm{~d}$ period in November-December I973 (Dickson, unpublished). Experimental pole arrays were installed, comprising regular and random patterns $\left(50 \mathrm{~m}^{2}\right.$ in area) at five sites and larger regular and random patterns ( $300 \mathrm{~m}^{2}$ in area) at a central site on the glacier.

The ice lost by calving of the glacier terminus was estimated from surveys of the lake depth and the position of the terminus.

Repeat aerial photographs were taken in May 1975 for preparation of a map showing the change in the glacier surface since April 1971.

\section{Results}

The glacier balance year was defined as I May to 30 April. The most significant parameters, maximum balance $\bar{b}_{\mathrm{x}}$ and annual balance $\bar{b}_{\mathrm{a}}$, as defined by Mayo and others (1972), are listed in Table $I$ for the period $1969-75$. Precision of these terms is about $\pm 10 \%$. The measured balance variations are plotted in Figure 4 for the glacier years $1969-75$. Total 


\section{IVORY GLACIER}

\section{LEGEND}

Cotchment Baundary
Glacifier Boundory

Waier-level Recarder Site $\square$

Storoge Gouge

Climale Sireen

Marker pole

Pole array (Mistoclimot

Studyl for 1972-73 \& 1973-74
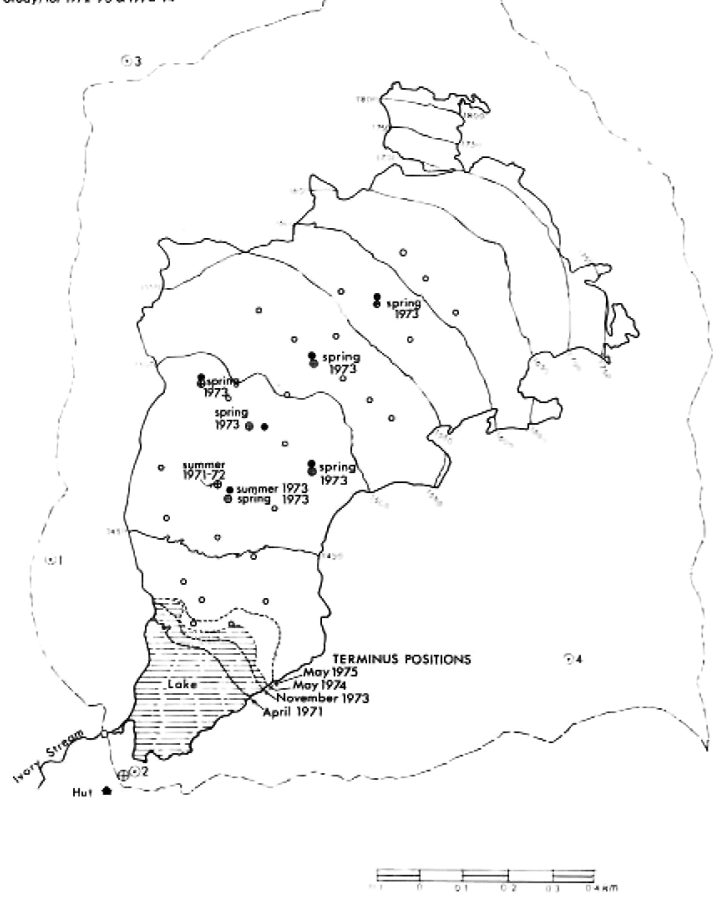

Contour Interval-Glacier Surface 50 o

Fig. 3. Map of Ivory Glacier showing pole network for mass-balance studies, locations of storage gattges, locations of microclimate measurements, and changes in termimus position 1971 to 197.5 . 
annual ablation increased during the study period, while snow accumulation appears to have been moderate during the glacier ycars $1970-73$ and well below average for the remainder of the period. Annual balance was consistently negative and became even more negative during 1973-75. In part, the increase in ablation may be related to the disappearance of most of the remnants of firn in the firn area during the period of study. By May 1975 the glacier had retreated significantly from its terminal position in 1969 .

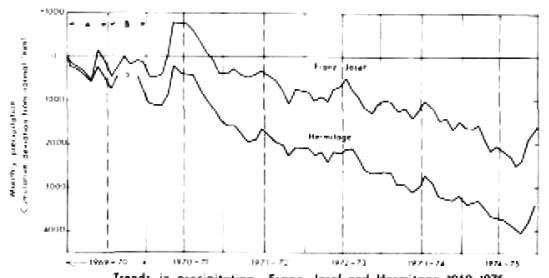

Trends in precipilation, Franz Jouet and Hermitoge 1969-1975

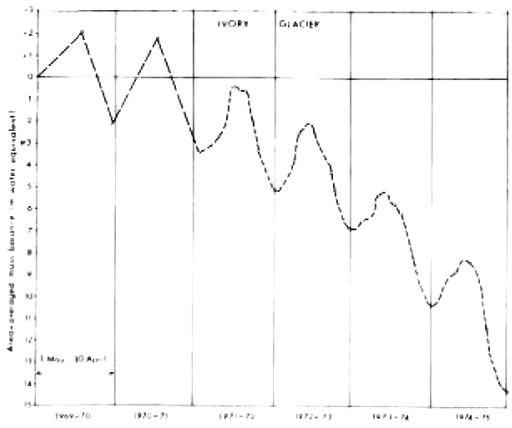

Irends in mass balance. Irory Glacier, 1989-1975

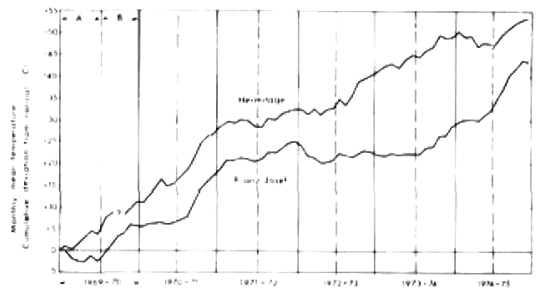

frends in lemperature. Frans laset and Hermitage 1969-75

Fig. 4. Trends in mass balance of Ioory Glatier, and precipilation and Lemperalure at Franz Josef Glacier and the Hermitage for the period $1969-75 . A-$ accumulation season, $B$ - ablation season. Precipitation normal $194^{I-70}$. Temperalure normal $1933^{-60}$. 
TABle I. Mass halance parameters, Ivory Glacier, ig69-75

\begin{tabular}{|c|c|c|}
\hline Glacier year & $\begin{array}{c}\text { Maximum balance, } b_{\mathbf{x}} \\
\text { (area-averaged }) \\
\text { m }\end{array}$ & $\begin{array}{c}\text { Annual balance, } b_{\mathrm{a}} \\
\text { (area-averaged) } \\
\mathrm{m}\end{array}$ \\
\hline $1969 / 70$ & $+2.05^{*}$ & $-2.1 I^{*}$ \\
\hline $1970 / 71$ & $+3.92^{*}$ & $-1.32^{*}$ \\
\hline $1971 / 72$ & +3.03 & -1.66 \\
\hline $1972 / 73$ & +3.11 & -1.73 \\
\hline $1973 / 74$ & +1.62 & -3.48 \\
\hline $1974 / 75$ & +2.05 & -4.00 \\
\hline
\end{tabular}

The accumulation season usually extends from May to October but significant variation can occur. During $1969-75$ snow accumulation from May to July was usually less than that from August to October.

The study of sampling efficiency of the pole network coincided with a period of alternating snow and rain. Statistical analysis of the data shows little spatial variation in surface change within each experimental pole array or between different types of array at each site. Random and regular pole arrays are equally efficient, and a single pole at each site adequately measures ablation (surface change) of snow-pack with an accuracy of $\pm 10 \%$ over an area as large as $600 \mathrm{~m}^{2}$. Accumulation was spatially more variable and less accurately determined. 7 to 15 poles would be adcquate to measure snow-pack ablation over the glacier, but the existing network of 30 poles is probably necessary to record accumulation satisfactorily. The transverse lines of poles are of greater sampling significance than the longitudinal central line.

\section{WATER BaLANGE}

Run-off: measurement

A water-level recorder (Fischer and Porter type) was installed in April 1970 at a site called "Ripplerock" (Fig. 5) on the stream draining from the proglacial lake. The stilling well was damaged shortly afterwards by small icebergs rafted down-stream from the lake. In March 1971 the recorder was replaced by a pressure-bulb recorder (Foxboro type) less vulnerable to damage. Various designs were prepared for a roofing structure to keep the recorder site clear of snow during winter. Prohibitive expense and the difficulty of protecting the structure from icebergs caused these plans to be abandoned. Observations have shown that stream flow is very low or non-existent at times when the gauging site is covered by snow and that large storms at the start of the melt season rapidly clear the channel. Consequently the errors in winter records are not likely to affect the computation of annual water balance significantly.

Stream flow was measured by current-meter gaugings; a slack-line cableway was used to gauge flood flows.

\section{Run-off: results}

Water-level records from the "Ripplerock" site were obtained from April 1971 to May 1975 with some gaps during winter months. Values of daily and monthly mean discharge were computed for the glacier years $1971 / 2-1974 / 5$. The accuracy of the computed values of daily mean discharge is about $\pm 5^{-10} \%$. The maximum value of $12.0 \mathrm{~m}^{3} / \mathrm{s}\left(55^{80} \mathrm{l} / \mathrm{s} \mathrm{km}^{2}\right)$ for daily mean discharge was recorded in March 1974. Monthly mean discharge values, averaged for the period 197I-75, are shown in Table II and indicate a pattern of low winter flows (June-August) moderate spring and summer flows, with a marked peak in November, and maximum flows in autumn (March-April). 


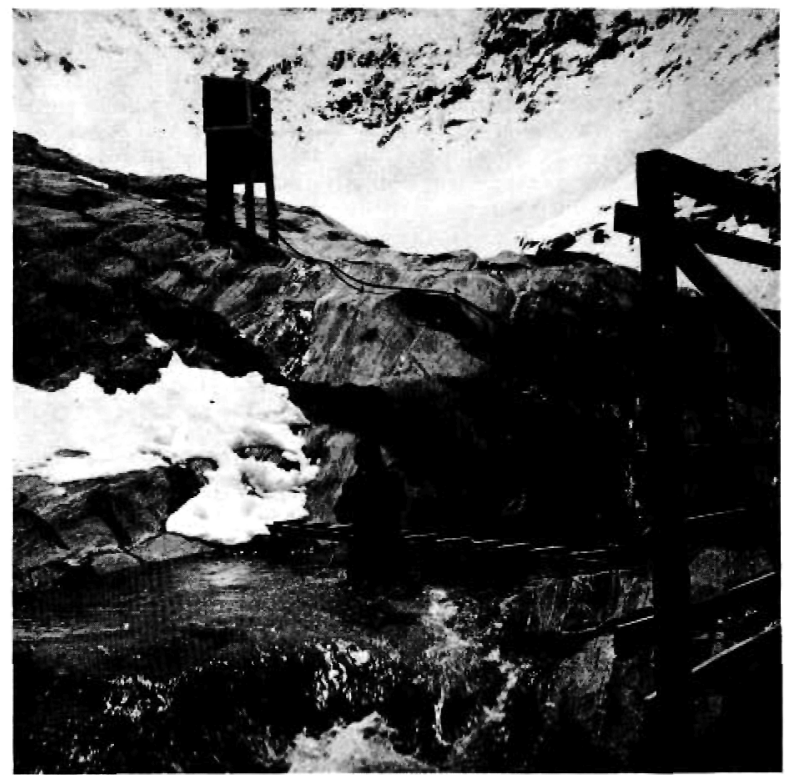

Fig. 5. "Ripplerock" recorder sile.

TABLE 1I. MEAN MONTHLY PREgiptTation AND RUN-OFF, IVORY BASIN, 197//2-1974/5

$\begin{array}{lcc}\text { Mean precipitation } & \begin{array}{c}\text { Mean ron-off } \\ \text { at site } 2 \\ \text { mm }\end{array} & \begin{array}{c}\text { at Ripplerock } \\ 1 / \mathrm{s}\end{array} \\ \text { May } & 569 & 467 \\ \text { June } & 429 & 306 \\ \text { July } & 453 & 152 \\ \text { August } & 392 & 63 \\ \text { September } & 704 & 565 \\ \text { October } & 1116 & 899 \\ \text { November } & 1012 & 1219 \\ \text { December } & 537 & 860 \\ \text { January } & 394 & 804 \\ \text { February } & 465 & 949 \\ \text { March } & 887 & 1297 \\ \text { April } & 1126 & 1235\end{array}$




\section{Precipitation: measurement}

Four storage gauges of $3000 \mathrm{~mm}$ capacity and fitted with alter shields were installed (Fig. 3). The gauges were raised up to $4 \mathrm{~m}$ above ground to maintain the orifices above maximum snow level. All sites are exposed, but site 2 near the lake shore is relatively sheltered by moraines. Daily manual records of precipitation at site 2 were obtained for a 6 month period over the 1972 winter. During the summer period from November to May, when most precipitation occurs as rain, a tipping-bucket rain gauge was operated at site 2 . No suitable gauges were available for long-term recording of large snowfalls, but a simple recording storage gauge was tested at the site.

\section{Precipitation: results}

Precipitation measurements were subject to considerable errors. The catches of the storage gauges were clearly related to the degree of exposure at the site and the orifices of gauges $\mathrm{I}, 3$ and 4 were also often blocked by snow or rime. Consequently, no meaningful pattern of basin precipitation was determined.

The records from site 2 are considered to be a reasonable index of basin precipitation. For periods when continuous records were not obtained, the storage totals have been corrected to monthly estimates by correlation with records from the nearest automatic rain gauge in the adjacent Hokitika representative basin. Monthly precipitation values, averaged for the period 197 I-75 are listed in Table II. Precipitation shows a major peak in spring (September to November) and a lesser peak in the autumn (March and April). The annual mean (glacier year) for the period $197^{\circ-75}$ is $8247 \mathrm{~mm}$.

\section{Water-balance estimates}

The annual water balance of the Ivory basin for the glacier year can be expressed as

$$
P=Q+E \pm \Delta I,
$$

where $P$ is precipitation, $Q$ is run-off, $E$ is evaporation and $\Delta I$ is the change in storage of perennial snow and ice (annual mass balance). Ground-water storage and sub-surface outflow are negligible and changes in storage of liquid water within the glacier from year to year are assumed to be negligible.

Two components of the water balance, run-off and annual mass balance, have been determined with a precision of about $10 \%$. However, the total precipitation for the basin has not been estimated satisfactorily, although the record from site 2 provides a reasonable index. No assessment has been made of annual evaporation. Short-term microclimate measurements have shown that evaporation loss is not significant on the glacier during the melt season, but evaporation from the lake may be significant. An estimate of annual evaporation has been derived from a formula given by Turc (1954) using assumed values of $9500 \mathrm{~mm}$ for annual precipitation and $2.5^{\circ} \mathrm{C}$ for mean annual temperature. This estimate indicates that annual evaporation is about $5 \%$ of the annual precipitation.

Neglecting evaporation, the measured and computed quantities related to the water balance are listed for the glacier years $1971 / 72-1974 / 75$ in Table III. The area-averaged quantities refer to the entire basin. The difference between run-off and annual mass balance (corrected for calving loss) provides a minimum estimate of basin precipitation. Estimated values of mean precipitation for the basin for the glacier years 1971-75 are similar for each year with a mean of $9630 \mathrm{~mm}$. Measured annual precipitation at site 2 for the same period also shows little variation between years with a mean of $8080 \mathrm{~mm}$. The rain gauge at site 2 could well have a catch deficiency of $20 \%$. 
Tabi. III. Summary of QUantities reiated to annual. Water bai.ANGe, Ivoky basin, 1971/72-1974/75

Quantity

Run-off, $\bar{\phi}_{\mathrm{m}}$

Annual mass balance, $b_{\mathrm{a}}$

Annual ice loss by calving, $b_{\mathrm{a}}$ (c)

Precipitation ( $\equiv \bar{q}_{\mathrm{a}}+b_{\mathrm{a}}+b_{\mathrm{a}}(\mathrm{c})$ )

Precipitation $\dagger$ at site 2

Snow and ice melt on glacier

Total melt in basin

\section{Deritution}

Measured

Measured on glacier surface

Estimated from terminus surveys

Computed

Measured

Measured

Estimated from hydrograph $\begin{array}{cccc}1971 / 72 & 1972 / 73 & 1973 / 74 & 1974 / 75 \\ \text { w water equivalent } & \text { (area-averaged) } & \\ & \mathrm{m} & \mathrm{m} & \mathrm{m}\end{array}$

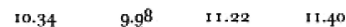

$\begin{array}{llll}-0.62 & -0.64 & -1.27 & -1.37\end{array}$

$-0.09^{*}-0.09^{*}-0.14 \quad-0.2 \mathrm{I}$

$9.63 \quad 9.25 \quad 9.8 \mathrm{I} \quad 9.8 \mathrm{I}$

$8.01 \quad 8.34 \quad 7.98 \quad 8.00$

$\begin{array}{llll}1.83 & 1.89 & 2.01 & 2.31\end{array}$

$\begin{array}{llll}2.45 & 2.15 & 1.97 & 2.36\end{array}$

* Two-year measurement distributed equally.

+ Point measurement.

Estimates of annual melt-water loss from the glacier were derived from the mass-balance parameters. The computed loss shows little variation between years for the glacier years $1971 / 72-1974 / 75$. However, the relative contributions of snow and melt ice melt differ significantly between years, depending on variations in snow accumulation (Fig. 6). Base flow determined from the hydrograph of daily mean discharge has been computed for each glacier year to obtain an estimate of total melt from the catchment. The resulting values of total melt are consistent with the glacier melt estimates.

The results show that melt from the Ivory basin contributed $21 \%$ of run-off during the period $1971-75$, including melt of perennial snow and ice which contributed $9 \%$ of run-off (Fig. 6). Annual snow accumulation in the basin represents about $25 \%$ of total precipitation.

Using the ratio between estimated basin precipitation and measured precipitation at site 2 for $1971-75$, the monthly precipitation values for site 2 have been corrected to provide estimates of mean monthly precipitation for the basin. The difference between precipitation and run-off has been computed for each month to determine the pattern of storage and melt run-off for the study period. These values are listed in Table IV and show a net gain from May to October with net loss from November to April. The data indicate that accumulation was greater during the period August to October than during May to July, while melt run-off was greatest during January to March.

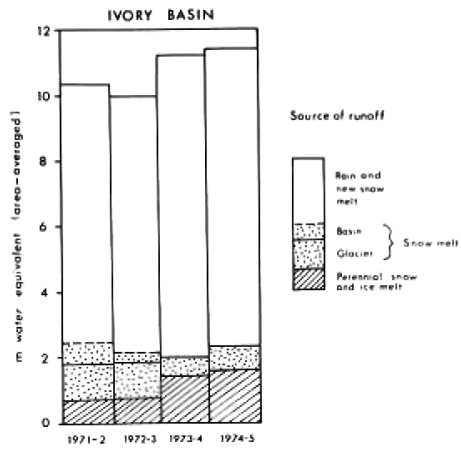

Fig. 6. Components of atunat run-off $197 / 7 / 2-1974 / 75$. 
TABLe IV. Estimates of Monthly MEsN water halange, IVORy Basin, $1971 / 7^{2-1974 / 75}$

$\begin{array}{lccc}\text { Mean run-off } & \begin{array}{c}\text { Estimated } \\ \text { precipitation } \\ \text { (arec-nueraged) }\end{array} & \begin{array}{c}\text { Estimated water } \\ \text { balance } \\ \text { (area-averaged) } \\ \text { (area-averaged) }\end{array} \\ \text { May } & \text { mm } & 57 & +95 \\ \text { June } & 582 & 677 & +142 \\ \text { July } & 369 & 511 & +388 \\ \text { August } & 189 & 539 & +388 \\ \text { September } & 68 . & 466 & +157 \\ \text { October } & 1120 & 838 & +208 \\ \text { November } & 1470 & 1328 & -266 \\ \text { December } & 1071 & 1204 & -432 \\ \text { January } & 1002 & 639 & -533 \\ \text { February } & 1068 & 469 & -515 \\ \text { March } & 1616 & 553 & -560 \\ \text { April } & 1489 & 1056 & -149\end{array}$

\section{Climatology}

\section{Long-term records}

Climatological instruments were installed near the hut (Fig. 2) to provide manual records during periods of occupation of the hut and automatic records for periods of up to three months between visits. A particularly valuable series of winter observations was compiled by a volunteer observer from May to November 1972. Continuous records of rainfall were obtained during each melt season from 1971 to 1975 and wind-run was also recorded for long periods during $1971-75$. Temperature records were intermittent but include some 4 to 8 month sequences. During the summers of $1970 / 71$ and $1971 / 72$, short-wave radiation was recorded for long periods.

\section{Short-term microclimate studies}

Three separate studies were carried out in conjunction with the Geography Department, University of Canterbury.

Study $r, 1971 / 72$ : The first part of this study occupied a $33 \mathrm{~d}$ period in NovemberDecember $197 x$ characterized by alternating snow-storms and rain-storms. The remainder of the study occupied a $45 \mathrm{~d}$ period in January-February 1972 with relatively calm weather including long periods with a clear sky. Microclimate and ablation/accumulation measurements were taken at a central site on the glacier to determine the energy balance at the surface by the aerodynamic method (Harding, unpublished). Environmental and instrumental problems encountered during the first phase of the study produced data of poor quality, however, during the second phase, better results were obtained over a melting ice surface.

Study 2, 1973: Microclimate and ablation measurements were recorded over a melting ice surface at a central site on the glacier for a period of $17 \mathrm{~d}$ during January-February 1973 . Improved equipment and instruments were installed to determine the energy balance by the aerodynamic method. Measurements at the central site were supplemented by ablation and precipitation measurements at four subsidiary sites on the glacier (Fig. 3).

Study 3, 1973: This study occupied a $35 \mathrm{~d}$ period during November-December 1973. Frequent storms with alternating rain and snow occurred during the first $23 \mathrm{~d}$. The programme was similar to study 2 and it was planned to obtain comparable results over a melting snow surface. A central site and five subsidiary sites were established for the measurement of basic meteorological variables and ablation/accumulation. Failure of the radiometers prevented measurement of net radiation during this study. 
Results of microclimate studies

Energy-balance parameters have been computed for a $30 \mathrm{~d}$ period in January-February 1972 and a $17 \mathrm{~d}$ period in January-February 1973. A summary of components of the energy balance for these two periods is given in Table $\mathrm{V}$ (personal communication from $\mathrm{J}$. E. Hay). The net radiative flux dominates in both cases, accounting for over $50 \%$ of the heat available for ablation. Sensible-heat flux ranks second in importance, but latent-heat flux is also significant, and was equivalent to the sensible-heat flux during the second study period. The energy-balance results show a greater contribution from latent-heat flux than similar measurements on other mid-latitude alpine glaciers and in this respect are more similar to the energybalance data recorded on high-latitude maritime glaciers such as the Worthington Glacier, Alaska (Streten and Wendler, 1968) and the Ampère Glacier, Kerguelen (Laboratoire de Glaciologie report in Ice, No. 49, r975, p. 3).

TABle V. COMponents of surface, energy balange, Ivory Glacter

\begin{tabular}{|c|c|c|c|c|c|c|}
\hline Study period & $\underset{\substack{\text { Nel } \\
\mathrm{m} \mathrm{J} / \mathrm{m}^{2}}}{\text { radiative flux }}$ & $\begin{array}{c}\text { Sensible-heat } \\
\text { fux } \\
\mathrm{mJ} / \mathrm{m}^{2}\end{array}$ & $\begin{array}{c}\text { Latent-heat } \\
\text { flux } \\
\mathrm{mJ} / \mathrm{m}^{2}\end{array}$ & $\begin{array}{c}\text { Heat } \\
\text { content of } \\
\text { precipitation } \\
\mathrm{mJ} / \mathrm{m}^{2}\end{array}$ & $\begin{array}{c}\text { Total } \\
\text { beat input } \\
\mathrm{mJ} / \mathrm{m}^{2}\end{array}$ & $\begin{array}{c}\text { Ablation } \\
\mathrm{m}\end{array}$ \\
\hline $197^{2}$ to 14 February $197^{2}$ & 212 & 131 & 44 & Io & 397 & 1.32 \\
\hline y 1973 to 14 February 1973 & $\begin{array}{c}137 \\
\%\end{array}$ & $\begin{array}{c}65 \\
\%\end{array}$ & 59 & $\begin{array}{l}6 \\
0\end{array}$ & $\begin{array}{l}267 \\
0\end{array}$ & 0.89 \\
\hline $97^{2}$ to $\mathrm{I}_{4} \mathrm{Feb}$ & 53 & 33 & 11 & 3 & 100 & \\
\hline 1973 to 14 February 1975 & 51 & 25 & 22 & 2 & 100 & \\
\hline
\end{tabular}

1. 5.January 1972 to 14 February $197^{2}$

2. 28 January 1973 to 14 February 1973

1. 5 January $197^{2}$ to 14 February $197^{2}$

2. 28 January 1973 to 14 February 1975

An energy-balance model relating climatological parameters to ablation and run-off was developed from the 1973 data and tested independently on the 1972 data (personal communication from J. E. Hay). Lack of radiation measurements prevented computation of energy balance for the third study period, so the energy-balance results only represent periods of relatively calm weather over a melting ice surface.

Prior to the study it was expected that the heat content of precipitation would be a significant component of the energy balance. During the periods for which energy-balance data are available only one major storm occurred and consequently the heat content of precipitation is insignificant for these periods. However the heat content of precipitation is significant during major rain-storms and must be an important component of the energy balance during the spring and autumn months of high precipitation. The precipitation (454 $\mathrm{mm}$ at site 2) from the single major storm during study 2 accounted for $19 \%$ and $1 \mathrm{r} \%$, respectively, of the daily heat input for two successive days. A significant proportion of the surface change recorded during this storm also appears to have been caused by erosion of the weathered ice crust by rain.

During November 1974 two major storms were recorded. The heat content of rain from the first storm ( $400 \mathrm{~mm}$ at site 2) was estimated to be sufficient to melt $28 \mathrm{~mm}$ water equivalent of snow-pack, about $45 \%$ of the recorded ablation during the storm. The succeeding storm ( $360 \mathrm{~mm}$ at site 2) again contributed sufficient heat from precipitation to melt $24 \mathrm{~mm}$ water equivalent of snow-pack.

Spatial variation of meteorological variables was investigated in the third study (Dickson, unpublished). Mean air temperature on the glacier is influenced more by aspect than by altitude. The cirque walls strongly influence wind direction and speed and create characteristic eddy patterns. Consequently, precipitation varies considerably over the glacier and shows no consistent relationship with altitude. Relative humidity is usually high $(>80 \%)$ and shows little spatial variation. Temperature profiles obtained during this study indicated 
that unstable conditions occurred frequently, suggesting that energy exchange would have been extremely difficult to determine by the acrodynamic method. The first two studies indicated that drainage of cold air during calm conditions causes temperature inversions.

\section{INSTRUMENTATION}

The results of testing a number of climatological instruments in the basin are summarized below. Lack of a convenient power source limited the choice to battery-powered instruments. Some of the electronic components were affected by the high humidity characteristic of the basin and sensors and cables required protection from kea parrots which are common in the area.

Multichannel event recorder: This instrument is a modified water-level recorder (Fischer and Porter type) described by Patterson (1972). Successful tests were carried out with three channels linked, respectively, to a tipping-bucket rain gauge, an anemometer, and a solarimeter and the recorder was able to operate unattended for 3 months.

Cup-counter anemometer: A standard totalizing anemometer was modified to register every $10 \mathrm{~km}$ of wind-run on the multichannel recorder.

Integrators: These were designed initially for integrating totals of short-wave and net radiation for microclimate studies. Integrators were also designed for long-period event recording of short-wave radiation and for long-period recording of hourly mean air temperature. All functioned satisfactorily.

Printing-counter recorder: This instrument is a modified version of the recorder described by Patterson (1971). It was tested with a solarimeter and later with a temperature sensor but could not operate for long periods unattended at the Ivory site.

Temperature recorder: A standard temperature recorder (Rimco type) operated for long periods without attention.

Temperature/humidity recorder: A recorder (Atkins type) linked to temperature and dewpoint probes was used for mast profile measurements. The dew-point probes overheated in the high humidity conditions and were modified to record wet-bulb air temperatures.

Recording rain gauge: A storage rain gauge comprising a $3 \mathrm{~m}$ polyvinylchloride cylinder fitted with a pressure-bulb recorder was installed at site 2. This instrument appears to be useful for remote sites in high-precipitation regions. An alter shield was fitted to the gauge but no reliable method was devised to prevent intermittent freezing of the contents during winter.

\section{REPRESENTATIVENESS OF THE IVORY BASIN}

To assess the representativeness of the precipitation data from the Ivory basin, annual precipitation totals for site 2 from 1970 to 1974 have been compared with the annual precipitation at the nearest climatological stations on the western edge of the Southern Alps and at the Hermitage on the eastern side of the range (Fig. 1, Table VI). The pattern of variation from I970 to 1974 at the Hokitika, Hari Hari, Franz Josef Glacier and Hermitage stations is similar to the Ivory Glacier record. For the glacier years $197 \mathrm{I}-75$, annual precipitation at Ivory site 2 showed little variation. Over the same period and also for $1970-71$ all three of the above climatological stations recorded little variation in annual (glacier year) precipitation. The correlation between annual precipitation at the Ivory basin and at the regional stations extends to monthly patterns for the period when continuous records arc available from the basin. Precipitation at Ivory Glacier does appear to be representative of regional trends.

The representativeness of stream-flow patterns in the Ivory basin cannot be assessed in the absence of comparative records from other glacier basins west of the alpine divide. 
Table VI. Comparison of annual pregipttation at Ivory basin with annual PRECIPITATION AT REGIONAL CLIMATOLOGICAL STATIONS

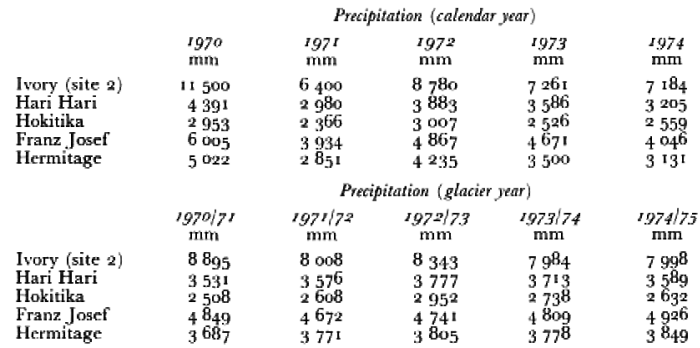

Assessment of the representativeness of the trends in mass balance shown by Ivory Glacier is difficult. The measured mass-balance fluctuations for $1969-75$ are shown in Figure 4 together with the cumulative deviations from normal of monthly mean temperature and monthly precipitation at the Hermitage and Franz Josef Glacier for the same period. Precipitation in the alpine regions was below normal for most of the period. Temperaturcs for both stations were generally above normal during $1969-75$, and consistently above normal during the ablation seasons. At Franz Josef Glacier temperatures during the accumulation season were close to or below normal, but at the Hermitage temperatures were above normal during the winters of 1969,1970 and 1973 . The evidence from these stations of reduced precipitation during the accumulation season and increased temperatures during the ablation season is consistent with the mass-balance fluctuations and negative balance trend observed at Ivory Glacier.

Direct comparison of the balance trends shown by Ivory Glacier with the behaviour of other glaciers in the region is difficult. Comparison can be made between the mass-balance parameters (area-averaged) recorded from Ivory Glacier and the mass balance parameters (specific) recorded from Tasman Glacier during 1969-75 (Anderton, 1975). Total annual ablation at Ivory Glacier and at Tasman Saddle show a similar pattern of variation, but

Table Vil. Comparison of mass-balance parameters measured on ivory and Tasman Glaciers. $1969 / 70-1974 / 75$

All quantities are expressed in water equivalent

Ivory Glacier

\begin{tabular}{|c|c|c|c|c|c|}
\hline$\underset{\mathrm{m}}{\operatorname{s} 669 / 70}$ & $\begin{array}{c}1970 / 71 \\
\mathrm{~m}\end{array}$ & $\underset{\mathrm{m}}{197^{1 / 7^{2}}}$ & $\begin{array}{c}1972 / 73 \\
\mathrm{~m}\end{array}$ & $\begin{array}{c}1973 / 74 \\
\mathbf{m}\end{array}$ & $\begin{array}{c}1974 / 7 \\
\mathrm{~m}\end{array}$ \\
\hline$+2.1^{*}$ & $+3.9^{*}$ & +3.0 & +3.1 & +1.6 & +2.1 \\
\hline$+4 \cdot 3^{*}$ & $+4.1 *$ & $+5-5$ & +6.3 & +4.8 & $+4 \cdot 3$ \\
\hline$-4 \cdot 2$ & $-5.2^{*}$ & -4.7 & -4.8 & -5.1 & -6.1 \\
\hline$-3.0^{*}$ & $-2.1^{*}$ & $-t .3$ & -2.3 & -2.5 & -3.4 \\
\hline - & - & -6.0 & -6.0 & -8.5 & -7.5 \\
\hline- & - & -12.0 & - I 1.2 & $-14,0$ & \\
\hline
\end{tabular}

Maximum balance, $b_{\mathbf{x}}$ (area-avera

Tasman Glacier (Saddle)

Maximum balance, $b_{\mathrm{x}}$ (specific)

Ivory Glacier

Annual ablation (area-averaged)

Tasman Glacier (Saddle)

Annual ablation (specific)

Ivory Glacier

Annual ice balance, $b_{\mathrm{a}}$ (i) at terminus (specific)

Tasman Glacier (Ball Hut)

Annual ice balance, $b_{\mathrm{a}}(\mathrm{i})$ (specific)

* Based on surveys close to time of maximum snow-pack or end of glacier year. 


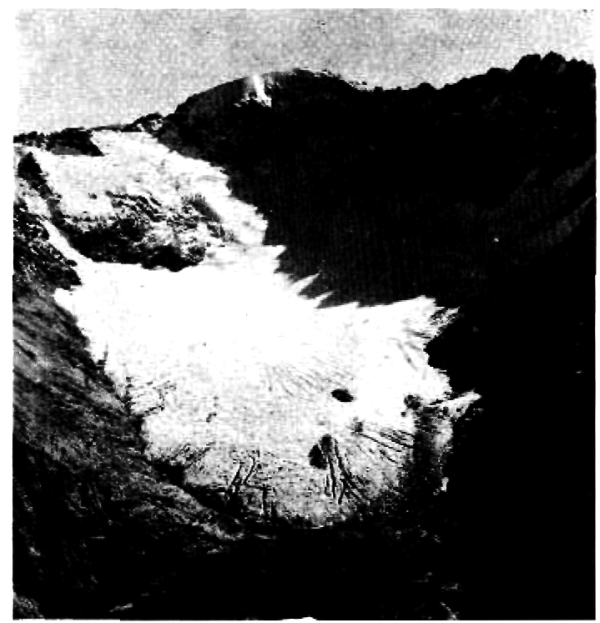

(a)

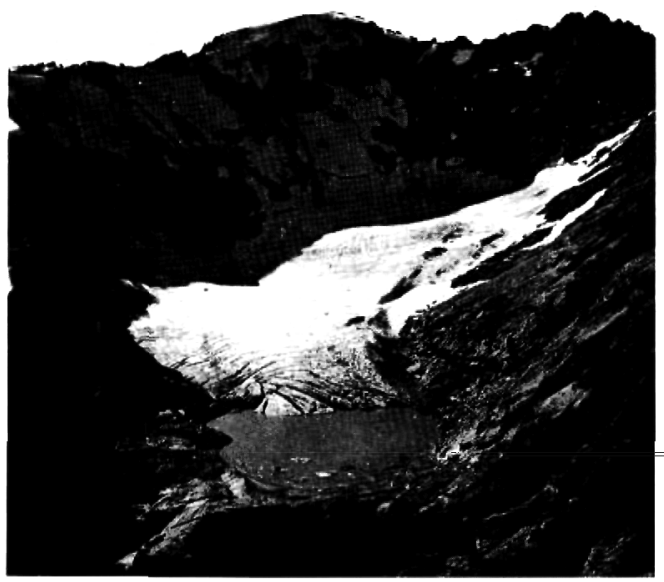

(b)

Fig. 7. Itory Glacier, (a) April 1953 (aboce); (b) April 1976, showing marked thinning and retreat (below). 
maximum balance at Ivory Glacier is not simply correlated with maximum balance at Tasman Saddle (Table VII). However annual ice balance (specific) on the tongue of Ivory Glacier is well correlated with annual ice balance (specific) at Ball Hut on Tasman Glacier for $197 \mathrm{I}-75$ (Table VII).

Since 1953 Ivory Glacier has thinned and retreated markedly (Fig. 7). During this period most glaciers in the Southern Alps have receded, except for small temporary readvances by Franz Josef and Fox Glaciers (Sara, 1970). The climate has warmed and glaciers have retreated rapidly in New Zealand from 1935 to 1975 (Salinger, 1976). Behaviour of Ivory Glacier therefore appears to be representative of the region.

The Ivory Glacier project terminated in May 1975. Precipitation measurements and a photographic record of the glacier terminus are being maintained. The glacier has been included in an annual programme of aerial photography of selected glaciers which commenced in 1977 .

\section{Acknowledgements}

The project was operated by the Water and Soil Division of Ministry of Works and Development. Many members of its hydrological survey staff assisted with great enthusiasm. Microclimate studies were undertaken by students from the Geography Department, University of Canterbury, under the guidance of Dr D. E. Greenland, and Dr J. E. Hay. Assistance and support from members of the Glaciology Working Group set up to coordinate the project is gratefully acknowledged.

MS. received 25 April 1977

\section{REFERENGES}

Anderton, P. W., comp. 1975. Tasman Glacier 1971-73. Wellington, Ministry of Works and Development for the National Water and Soil Conservation Organisation. (Hydrological Research: Annual Report No. 33.)

Anderton, P. W., comp. I976[a]. Ivory Glacier, representative basin for the glacial hydrological region 1972-73. Wellington, Ministry of Works and Development for the National Water and Soil Conservation Organisation. (Hydrological Research: Annual Report No. 35.)

Anderton, P. W., comp. 1976[b]. Inory Glacier, representatice basin for the glacial hydrological region 1979-75. Wellington, Ministry of Works and Development for the National Water and Soil Conservation Organisation. (Hydrological Research: Annual Report No. 36.)

Anderion, P. W., and Chinn, T. J., fomp, I973. I lory Glacier, representative basin for the glacial hydrological region. Report No. 2, April $1969-$ May $197^{1 .-R e p o r t ~ N o . ~ 3, ~ M a y ~} 197^{7-A p r i l} 197^{2}$. Wellington, Ministry of Works for the National Water and Soil Conservation Organisation. Hydrological Research: Annual Report No. 28.)

Chinn, T. J. 1969. Snow survey techniques in the Waitaki catchment, south Canterbury. Fournal of Hydrology (New Zealand), Vol. 8, No. 2, p. 68-76.

Chinn, T. J., and Bellamy, R. J. 1970. Ivory Glacier, represenlative basin for the glacial hydrological region for the period ended $3^{I}$ December sg6. Wellington, Water and Soil Division of the Ministry of Works for the National Water and Soil Conservation Organisation. (Annual Hydrological Research Report No. 5.)

Dickson, B. Unpublished. Glacio-meteorological research on the snowpack surface of the Ivory Glacier. [M.A. thesis, University of Canterbury, Christchurch, New Zealand, 1974.]

Goldthwait, R. P., and McKellar, I. C., 1962. New Zealand glaciology. (In Wexler, H., and others, ed. Antarctic research. [Edited by] $H$. Wexler, M. J. Rubin and J. E. Caskey, Jr. Washington, D.C., American Geophysical Union, p. 209-16. (Geophysical Monograph Series No. 7.))

Harding, F, B. Unpublished. Micrometeorological investigations over a mid-latitude temperate glacjer-the Ivory Glacier. [M.A. thesis, University of Canterbury, Christchurch, New Zealand, 1972.]

Mayo, L. R., and others. 1972. A system to combine stratigraphic and annual mass-balance systems; a contribution to the International Hydrological Decade, by I. R. Mayo. M. F. Meier and W. V. Tangborn. Journal of Glaciologr, Vol. 11 , No. 61, p. 3-14.

New Zealand. National Water and Soil Conservation Organisation. 1970. Representative basins of Vew Zealand 1970. Published as a New Zealand contribution to the UNESCO International Decade, 196,-197.5. Wellington, Water and Soil Division of the Ministry of Works for the National Water and Soil Conservation Organisation. (Miscellaneous Hydrological Publication No. 7.) 
Patterson, J. E. 1971. A combined event and fixed-time recorder. Jounal of Hydrology (New Zealand), Vol. ro, No. 2 , p. $141-44$.

Patterson, J. E. 1972. A multichannel recorder for hydrological research. Fournal of Hydrology (New Zealand), Vol. 11, No. 1, p. $55-61$.

Salinger, M. J. 1976. New Zealand temperatures since 1300 A.D. Nature, Vol, 260, No. 5549, p. 310-11.

Sara, W. A. 1968. Franz Josef and Fox Glaciers, $1951-67$. New Zealand Journal of Geology and Geophysics, Vol. 1 1, No. 3 , p. $768-80$.

Sara, W. A. 1970. Glaciers of Westland National Park. A New Zealand Geological Survey Handbook. [Wellington, N.Z.], New Zealand Dept. of Scientific and Industrial Research. (Information Series, 75.)

Streten, N. A., and Wendler, G. 1968 . The midsummer heat balance of an Alaskan maritime glacier. Journal of Glaciology, Vol. 7 , No. 5 i, p. $43^{1-40 .}$

Thompson, R. D., and Kells, B. R. 1973. Mass balance studies on the Whakapapanui Glacier, New Zealand. (In [International Hydrological Decade.] The role of snow and ice in hydrology, Procedings of the Banff symposia, September 1972. Paris, UNESCO; Geneva, WMO; Budapest, IAHS, p. 383-93. (Publication No. 107 de l'Association Internationale d'Hydrologie Scientifique.))

Toebes, C., and Palmer, B. R. 1969. Hydrological regions of New Zealand. Wellington, Water and Soil Division of the Ministry of Works for the National Water and Soil Conservation Organisation. (Miscellaneous Hydrological Publication No. 4.)

Turc, L. C. 1954. Calcul du bilan de l'eau évaluation en fonction des précipitations et des températures. Union Géadésique et Géophysique Internationale. Association Internationale d'Hydrologie Scientifique. Assemblée générale de Rome 19.54. Tom. 3. Comptes-rendus et rapports de la Commission des Eaux de Surface, p. 188-202. (Publication No. $3^{8}$ de $\mathrm{I} \%$ ssociation Internationale d'Hydrologie.) 